\title{
Miniature catfishes of the genus Gelanoglanis (Siluriformes: Auchenipteridae): monophyly and the description of a new species from the upper rio Tapajós basin, Brazil
}

\author{
Bárbara B. Calegari ${ }^{1}$, Roberto E. Reis ${ }^{1}$ and Richard P. Vari ${ }^{2}$
}

Previously proposed synapomorphies for the genus Gelanoglanis of the catfish family Auchenipteridae are evaluated and four additional features involving the relationship between the mesethmoid and premaxilla, the very fleshy anterior portion of the snout, the lack of ossification of the second through fourth infraorbitals, and the incomplete poring of the lateral line are hypothesized as synapomorphic for the members of the genus. A new species of Gelanoglanis is described based on a series of specimens collected in the rio Teles Pires, a tributary of the rio Tapajós in the southern reaches of the Amazon basin. The new species demonstrates a number of features unusual within Gelanoglanis including a fontanel bordered by the frontals, a particularly elongate gonopodium in mature males, reductions in the dentition on the premaxilla, and a shorter posterior extension of the maxilla inside the maxillary barbel. The new species is a miniature as evidenced both by its body size and the reductions of various ossifications of the head, the number of fin rays and of the laterosensory canal system on the head and body.

Sinapomorfias propostas previamente para o gênero Gelanoglanis da família Auchenipteridae são avaliadas e quatro características adicionais que envolvem a relação entre o mesetmóide e a pré-maxila, a porção anterior do focinho carnosa, a perda de ossificação do segundo ao quarto infraorbital e linha lateral incompleta são hipotetizadas como sinapomórficas para os membros do gênero. Uma espécie nova de Gelanoglanis é descrita com base em uma série de exemplares coletados no rio Teles Pires, um tributário do rio Tapajós na porção sul da bacia Amazônica. A espécie nova possui várias características incomuns dentro de Gelanoglanis, incluindo uma fontanela bordeada pelos frontais, um gonopódio particularmente longo em machos maduros, redução da dentição na premaxila, e extensão posterior da maxila mais curta dentro do barbilhão maxilar. A espécie nova é uma miniatura, como evidenciado não apenas pelo tamanho reduzido do corpo, como também pela redução da ossificação da cabeça, do número de raios e do sistema de canais látero-sensoriais da cabeça e do tronco.

Key words: Amazon, Biodiversity, Endemism, Neotropics, Systematics.

\section{Introduction}

Gelanoglanis was proposed by Böhlke (1980) for a distinctive species of previously undescribed driftwood catfish, G. stroudi. This unusual, soft-bodied, new species was described from samples that originated in the río Metica and río Manacacias, both of which are whitewater tributaries to the río Orinoco in eastern Colombia. In his original description of G. stroudi, Böhlke (1980) discussed the relationships of the species and concluded that it was a member of the Auchenipterinae (the Auchenipteridae of present usage), but "not closely related to any described auchenipterine". Ferraris (1988) was the first author to resolve the phylogenetic placement of Gelanoglanis which he assigned to a monophyletic group composed by that genus, Centromochlus Kner, 1857, Glanidium Lütken, 1874, Tatia Miranda Ribeiro, 1911, plus two additional undescribed genera. Subsequently, Soares-Porto (1998) published a phylogenetic hypothesis of the Centromochlinae in which Gelanoglanis resolved as deeply nested within Centromochlus and hence she proposed a synonymy of Gelanoglanis into Centromochlus. Soon thereafter, SoaresPorto et al. (1999) reversed the synonymy proposed by Soares-Porto (1998) by their recognition of Gelanoglanis as valid in their description of a new species, G. nanonocticolus, from localities in the río Asisa, a blackwater tributary of the upper río Orinoco in southern Venezuela and from the middle rio Negro in the northern reaches of the Amazon basin. In

\footnotetext{
${ }^{1}$ Laboratório de Sistemática de Vertebrados, Pontifícia Universidade Católica do Rio Grande do Sul. Av. Ipiranga 6681, 90619-900 Porto Alegre, RS, Brazil. barbara.calegari@gmail.com, reis@pucrs.br

${ }^{2}$ Department of Vertebrate Zoology, National Museum of Natural History, Smithsonian Institution, Washington, DC, 20560 USA. varir@si.edu
} 
that publication, those authors recognized Gelanoglanis as a member of the subfamily Centromochlinae which they equated with the monophyletic group recognized as the family Auchenipteridae by Ferraris (1988). More recently, a third species of Gelanoglanis, G. travieso, was described by Rengifo et al. (2008); from the río Marañon, a whitewater tributary to the mainstream Amazon in northeastern Peru.

Analysis of a sample of Gelanoglanis collected in the rio Teles Pires within the upper reaches of the rio Tapajós basin, a southern tributary of the rio Amazonas, revealed it to represent a new species of the genus. This record is the first for the genus from the southern portions of the Amazon basin and also the first reported sample of Gelanoglanis originating in a clear water habitat. Comparative surveys identified additional synapomorphies for the species of Gelanoglanis, but also that one previously proposed synapomorphy for the species of the genus was lacking in the new form. Gelanoglanis has been considered a case of miniaturization within the Auchenipteridae, with the contained species reaching maximum standard lengths of $36 \mathrm{~mm}$ SL (Soares-Porto et al. 1999). Various reductive features observed in the new species described in the present study and its congeners corroborate the characterization of the genus as miniaturized.

\section{Material and Methods}

Morphometric measurements were obtained to the nearest $0.1 \mathrm{~mm}$ with digital calipers under a stereomicroscope, preferably on the left side of specimen, and follow Sarmento-Soares \& Martins-Pinheiro (2008) and Soares-Porto et al. (1998). Soares-Porto et al. (1998) and Rengifo et al. (2008) served as the source of the comparative information in the diagnosis of the new species. The count of vertebrae includes the terminal element associated with the hypural complex. This count assumes that the fifth vertebra, which lacks articulated ribs, is suturally united to the anterior four elements incorporated into the Weberian Complex and treats the first rib-bearing centrum as the sixth vertebra (Ferraris \& Vari, 1999). Osteological features were evaluated on specimens cleared and counterstained (c\&s) for bone and cartilage according to the technique of Taylor \& Van Dyke (1985). The term gonopodium herein refers to the intromittent organ of mature males. Abbreviations used in text are: SL, standard length and HL, head length. Museum abbreviations are: ANSP, The Academy of Natural Sciences, Philadelphia; CAS, California Academy of Sciences, San Francisco; LACM, Los Angeles County Museum, Los Angeles; MCP, Museu de Ciências e Tecnologia da Pontifícia Universidade Católica do Rio Grande do Sul, Porto Alegre; MZUSP, Museu de Zoologia da Universidade de São Paulo, São Paulo; SU, Stanford University, collections now at CAS, San Francisco; UF, Florida Museum of Natural History, Gainesville; and USNM, National Museum of Natural History, Smithsonian Institution, Washington, D.C.

\section{Results}

Gelanoglanis monophyly. Gelanoglanis has been to date diagnosed on its possession of a combination of multiple characters, six of which were proposed by Böhlke (1980) and subsequently utilized with some modifications by SoaresPorto et al. (1999). These are: 1- the pectoral-fin spine, if present, lacking serrations along its anterior margin; 2- the posterior naris being long, narrow, and located immediately anterior to the eye; 3 - the possession of a single pair of mental barbels; 4- the laterally situated contralateral premaxillary tooth patches widely separated at the jaw symphysis; 5- the mouth oblique and sinuous, with free fleshy flange around the angle of the mouth opening; and 6- the bases of all fins, except for the caudal fin, being short and the fins including relatively few fin rays. In their analysis Soares-Porto et al. (1999) noted that several of these features, albeit derived, occur homoplastically elsewhere in the Auchenipteridae. Those authors also advanced five additional characters that they hypothesized were diagnostic for Gelanoglanis: 7 - the absence of the third pectoral-fin radial; 8 - the mandibular ramus of the laterosensory canal being free from the dentary; 9 - the reduction of the mesopterygoid to a small, round ossification; 10- the absence of the vomer; and 11- the absence of an anterior fontanel.

Analysis revealed that Gelanoglanis pan, the species described herein, shares all the aforementioned synapomorphies except for 11- the absence of an anterior fontanel. Gelanoglanis pan conversely has a single, rounded to longitudinally ovoid fontanel bordered solely by the frontal bones. An undivided anterior fontanel is generally present among the remaining members of Centromochlinae except for Centromochlus existimatus Mees, 1974, and Tatia intermedia (Steindachner, 1877) in which the anterior fontanel is subdivided in two openings. When present the fontanel is generally margined by both the mesethmoid and frontal bones other than in Centromochlus altae Fowler, 1945, C. existimatus, Tatia jacaratia Pavanelli \& Bifi, 2009, T. meesi Sarmento-Soares \& Martins-Pinheiro, 2008, and T. neivai (Ihering, 1930), in which the anterior fontanel is margined solely by the frontals. In so far as an anterior fontanel is present in almost all taxa in the Auchenipteridae, the presence of that aperture in Gelanoglanis pan is potentially indicative of the basal position of that species within the genus (e.g., the absence of the fontanel being a synapomorphy for all congeneric species); however, a more encompassing phylogenetic analysis is necessary to evaluate this hypothesis.

Our analyses revealed four additional diagnostic and potentially synapomorphic features for Gelanoglanis above and beyond those put forward by Böhlke (1980) and Soares-Porto et al. (1999). The first of these is the anterior portion of the head with a very fleshy region anterior to the mesethmoid. As mentioned above, species of Gelanoglanis have a highly modified morphology of the cranium as exemplified by the arched mesethmoid and the lateral 
displacement of the premaxillae. This restructuring of the bones at the anterior region of the head is complemented by a thick layer of soft tissues over the anterior portion of the snout. Other members of Centromochlinae alternatively have the anterior portion of the snout formed by the skincovered mesethmoid.

A second additional synapomorphy for Gelanoglanis is the mesethmoid separate from the anteromedial portion of the premaxillae. In the remaining species of the Centromochlinae, the mesethmoid is in contact with the premaxillae along its length; with the contact in some instances being via a distinct suture. The thin arched mesethmoid of Gelanoglanis is instead anteromedially separate from the laterally displaced premaxillae.

The third diagnostic feature for Gelanoglanis is the lack of ossification of all infraorbital canals other than for the laterosensory canal segment and laminar projections along both the posterior and ventral margins of the canal within the first infraorbital. Remaining infraorbitals (2 to 4) are present as transparent, unossified, elongate, tubular structures.

The fourth and final additional synapomorphy is the incomplete lateral line. Although Soares-Porto et al. (1999) and Rengifo et al. (2008) assumed the lateral line to be complete across Gelanoglanis, our observations indicate that the lateral line is incomplete and terminates approximately at a vertical through the posterior terminus of the anal-fin base and well anterior to the caudal fin in all species of Gelanoglanis. This reduction resolves as synapomorphic for the species of Gelanoglanis, since all other genera of the Auchenipteridae have a lateral line extending posteriorly onto the caudal fin for about one-half the length of the caudal-fin rays, or when the lateral line is reduced, it at least reaches the caudal-fin base.

\section{Gelanoglanis pan, new species}

Figs. 1-2; 4-5

Gelanoglanis cf. stroudi.-Birindelli, 2014: 535, 544 (comparative material)
Holotype. MZUSP 114669, 24.7 mm SL, Brazil, Mato Grosso State, Itaúba, rio Teles Pires, tributary to upper rio Tapajós basin, $10^{\circ} 58^{\prime} 30^{\prime \prime S} 55^{\circ} 44^{\prime} 3^{\prime}$ "W, 1 Oct 2007, J. Birindelli \& P. Hollanda-Carvalho.

Paratypes. MZUSP 96032, 8, 10.8-12.9 mm SL + 1 c\&s, 20.2 mm SL; MCP 48078, 1, 14.8 mm SL; USNM 427060, 1, $13.8 \mathrm{~mm} \mathrm{SL}$; all collected with holotype.

Diagnosis. Gelanoglanis pan is distinguished from all congeners by the presence of an anterior middorsal fontanel situated between the anterior portions of the contralateral frontals ( $v s$. the frontals conjoined along the entirety of their middorsal margins and the fontanel absent); by adult males having a long fleshy, tubular gonopodium extending posteriorly to a point midway along the length of the anal fin (vs. the gonopodium reaching only to, or slightly beyond, the anal-fin origin in G. travieso and G. stroudi or falling short of the anal-fin origin in G. nanonocticolus); and by the deeper caudal-peduncle $12.1-13.5 \%$ SL (vs. $9.5-12.0 \%$ in $G$. stroudi, $10.2-11.6 \%$ in G. nanonocticolus, and $9.4-11.7 \%$ in G. travieso, see Rengifo et al., 2008). Gelanoglanis pan differs from G. stroudi and G. travieso by having the premaxillary teeth occupying one-half or less of the length of the premaxilla and restricted to the its more vertically expansive anterior portion (vs. the teeth distributed along most of the dentigerous margin of the premaxilla and occupying two-thirds of length of the bone); the portion of the maxilla inside the base of the maxillary barbel shorter and terminating posteriorly forward of the anterior margin of the opercle (vs. maxilla terminating posteriorly to the middle of the opercle); and by the larger orbital diameter 14.4-17.9\% HL (vs. 7.2-9.3\% in G. stroudi and 8.2-12.8\% in G. travieso; see SarmentoSoares et al., 1999). Gelanoglanis pan is additionally distinguished from $G$. nanonocticolus by having the pectoral- and dorsal-fin spines with well-developed serrae ( $v s$. pectoral- and dorsal-fin spines absent).

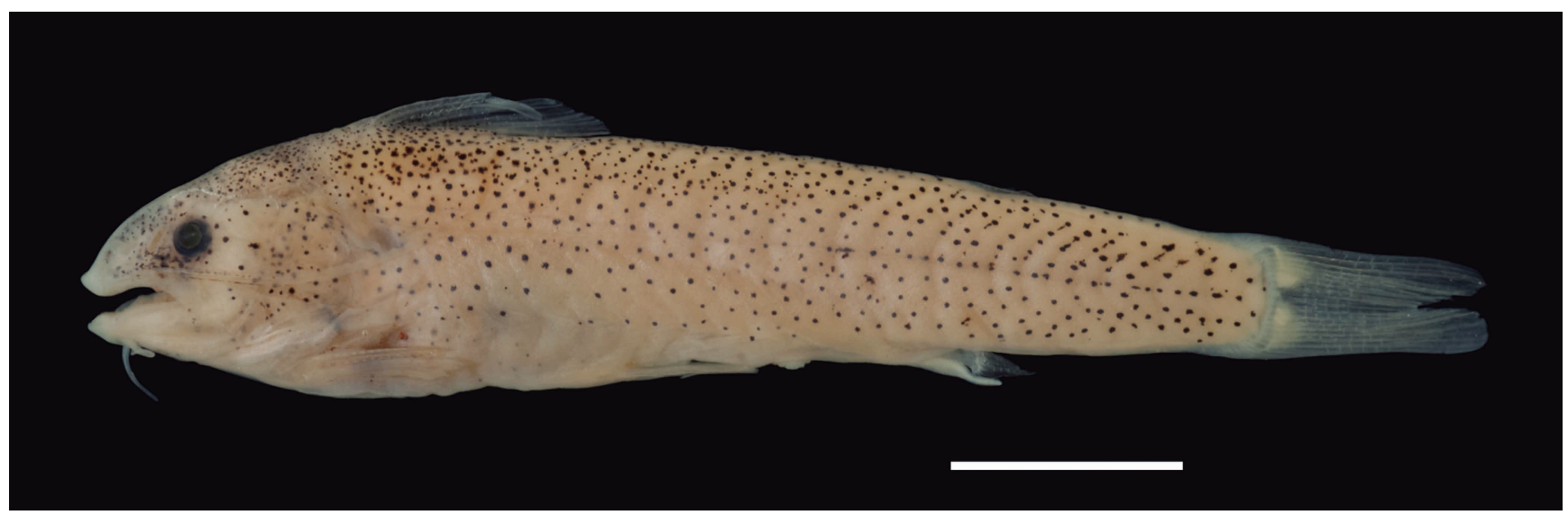

Fig. 1. Gelanoglanis pan, MZUSP 114669, holotype, male, $24.7 \mathrm{~mm}$ SL; Brazil, Mato Grosso State, Itaúba, rio Teles Pires, tributary to upper rio Tapajós basin; lateral views. Scale bar $=0.5 \mathrm{~cm}$. 
Description. Morphometric data presented in Table 1 . Standard length of examined specimens 10.8 to $24.7 \mathrm{~mm}$ SL. Head and body overall in form of laterally compressed cylinder. Dorsal profile of head distinctly convex from tip of snout to anterior region of frontal and slightly convex from middle of head to posterior limit of head. Dorsal profile of body slightly convex to rear of dorsal-fin base; straight from terminus of dorsal-fin base to end of caudal peduncle and angling slightly dorsally at insertion of first procurrent ray. Ventral profile of head and body slightly convex from lower jaw to vertical through tip of pectoral fin; then approximately straight to caudal peduncle. Greatest body depth at dorsal-fin origin; depth progressively decreasing posteriorly to posterior portion of caudal peduncle. Greatest body width at pectoralfin insertion and decreasing progressively posteriorly. Caudal peduncle strongly compressed.

Mouth terminal, with margin sinuously curved. Curvature commencing dorsally at anterior margin of lip, then curving ventrally before arching to its most dorsal position along vertical passing through anterior margin of posterior naris and base of maxillary barbel; margin then curving again ventrally to rictus of mouth. Lower lip with large, fleshy rictal flap, or epidermal flange, situated ventral to region of maximum dorsal curvature of margin of upper lip. Anterior portion of lower lip fleshy and extending forward as anteriorly tapering process beyond anterior limit of dentary. Fleshy contralateral upper lips meet medially along distinct arch at midline. Snout fleshy, more so anteriorly. Maxillary barbel arising ventral of posterior naris and extending posteriorly beyond vertical through pelvic-fin origin. Maxillary barbel in juveniles and adults of both genders with rugose dorsal surface resulting from series of welldeveloped rounded, regularly spaced, soft papillae arranged in single discrete row along length of barbel. Single pair of well developed mental barbels extends posteriorly beyond isthmus. Posterior naris in form of elongate, ovoid, posteromedially angled opening immediately anterior to orbit.

Dentary elongate and bearing narrow band of conical teeth with slightly posteriorly recurved tips. Lateral teeth of dentary oriented somewhat posteromedially. Anterior dentary teeth distinctly longer than remaining teeth on lower jaw; occupying area of dentary covered by fleshy flap. Premaxillary teeth similar in form to those of dentary, but slightly shorter than longer anterior teeth on latter bone. Contralateral premaxillae broadly separated medially. Each premaxilla with patch of dentition limited to anterior, more vertically expanded portion of bone.

Anterior middorsal fontanel present and bordered solely by frontals, and forming somewhat longitudinally ovoid opening situated anterior of vertical through orbit. First infraorbital ossified and large. Remaining four infraorbitals represented by transparent unossified tubes surrounding segments of laterosensory canal system. Lateral line unossified, incomplete, nearly straight except for sinuous curve anteriorly; extending along midlateral surface of body from post-temporal-supracleithrum approximately to vertical through posterior limit of anal fin.
Table 1. Morphometric data for holotype (Hol) and three largest paratypes of Gelanoglanis pan. Range includes holotype; $\mathrm{SD}=$ standard deviation.

\begin{tabular}{lccccc}
\hline & Hol & Low & High & Mean & SD \\
\hline Standard length (mm) & 24.7 & 12.4 & 24.7 & 16.4 & - \\
& Percents of standard length & & & \\
Head depth & 21.2 & 19.3 & 23.0 & 21.2 & 1.5 \\
Body width at pectoral-fin origin & 11.8 & 11.8 & 13.5 & 12.4 & 0.8 \\
Pre-isthmus length & 10.6 & 6.9 & 10.9 & 9.4 & 1.8 \\
Predorsal length & 27.0 & 27.0 & 28.8 & 28.2 & 0.8 \\
Dorsal-fin base length & 13.4 & 12.0 & 14.8 & 13.3 & 1.2 \\
Anal-fin base length & 8.2 & 6.4 & 10.0 & 7.8 & 1.6 \\
Preanal length & 69.7 & 67.7 & 71.7 & 69.9 & 1.7 \\
Caudal-peduncle depth & 12.1 & 12.1 & 13.5 & 12.6 & 0.6 \\
Dorsal-fin origin to pectoral-fin origin & 22.8 & 20.0 & 24.0 & 22.5 & 1.7 \\
Dorsal-fin origin to pelvic-fin origin & 32.7 & 32.7 & 38.4 & 35.2 & 2.5 \\
Pectoral-fin to pelvic-fin origin & 27.7 & 26.5 & 29.9 & 28.0 & 1.4 \\
Prepectoral length & 18.0 & 18.0 & 25.3 & 21.9 & 3.1 \\
Prepelvic length & 45.6 & 45.6 & 51.4 & 49.3 & 2.5 \\
Anal-fin to pelvic-fin origin & 25.2 & 18.9 & 25.2 & 20.9 & 2.9 \\
Anal-fin origin to hypural plate & 34.3 & 30.7 & 34.4 & 31.7 & 1.8 \\
Dorsal-fin depth & 22.5 & 22.1 & 28.2 & 23.8 & 2.9 \\
Adipose-fin depth & 15.7 & 12.1 & 19.8 & 16.4 & 3.3 \\
Longest anal-fin ray & 6.4 & 6.4 & 14.1 & 10.3 & 3.1 \\
Pectoral-fin length & 16.6 & 13.1 & 16.6 & 15.1 & 1.7 \\
Pelvic-fin length & 12.2 & 11.6 & 13.0 & 12.4 & 0.6 \\
Maxillary barbel length & 49.2 & 38.8 & 49.3 & 44.8 & 4.5 \\
Mental barbel length & 9.4 & 9.3 & 17.8 & 12.4 & 4.0 \\
Dorsal-spine length & 12.3 & 10.8 & 12.3 & 11.7 & 0.8 \\
Pectoral-spine length & 14.1 & 11.5 & 15.1 & 13.9 & 1.6 \\
First pelvic-fin ray length & 12.3 & 7.9 & 12.3 & 10.3 & 1.8 \\
Head length & 28.6 & 27.9 & 32.7 & 29.6 & 2.1 \\
& 28.8 & 26.1 & 37.9 & 31.5 & 4.9 \\
Head depth & 32.2 & 32.2 & 40.1 & 36.5 & 3.6 \\
Snout depth & & & & \\
Snout length & 74.0 & 65.2 & 74.0 & 68.6 & 4.1 \\
Orbital diameter & 45.5 & 45.1 & 52.2 & 48.7 & 3.9 \\
Interorbital distance & 31.9 & 31.6 & 33.2 & 32.2 & 0.7 \\
Gape width & 16.2 & 14.4 & 17.9 & 16.5 & 1.6 \\
Upper jaw length & 28.5 & 22.0 & 28.5 & 24.8 & 2.9 \\
\hline & & & & \\
& & &
\end{tabular}

Pseudotympanum apparent in larger individuals (13.8$24.7 \mathrm{~mm} \mathrm{SL}$ ) and located anterodorsally on lateral portion of body; opening situated posterior to margin of opercle and terminating posteriorly approximately at vertical through base of dorsal-fin spine. Pseudotympanum slightly horizontally elongate, with anterior portion narrower.

Dorsal-fin rays, II,5. Dorsal-fin spine robust, 5 to 7 welldeveloped serrae along posterior margin; posterior margin of spine not covered by skin. Bony spine continued distally as unsegmented filament approximately one-half length of spine. Pectoral-fin rays I,5. Adpressed pectoral-fin spine reaching posteriorly to vertical through middle of dorsal-fin base. Spine bearing 11 well-developed serrae along posterior margin. Adipose-fin origin located along vertical through posterior terminus of anal-fin base. Posterior margin not attached to body. Juveniles (10.8-12.4 mm SL) with long, fleshy, middorsal ridge arising at vertical through pelvic- 
fin origin and extending posteriorly to slightly beyond posterior terminus of anal-fin base. Fleshy ridge in juveniles gradually increasing in depth posteriorly and then abruptly terminating at rounded posterior margin. Pelvic-fin rays i,5; rays very short. Anal fin, iii,4,i. Anal fin of males with base of rays aligned at right angle to longitudinal axis of body. Anteroventral margin of fin supporting elongate gonopodium in males (see details in Sexual dimorphism). Caudal-fin rays, $\mathrm{i}, 15$,i; fin deeply forked. Total vertebrae, $34(\mathrm{n}=2)$.

Color in alcohol. Ground coloration of head and body whitish to yellowish cream. Head and body with numerous discrete chromatophores; chromatophores of large size in smaller individuals. Head with tiny to small black chromatophores and very small black spots; spots more intense on dorsal surface of head, region anterior to orbit and to lesser degree on opercle. Pigmentation on opercle more prominent in juveniles. Region under orbit plus lateral and ventral surfaces of jaw with sparse black chromatophores; these more concentrated near attachment area of mental barbels. Body covered with relatively evenly spaced, tiny to small black chromatophores and very small black spots other than for ventrally. Larger individuals with chromatophores on body more concentrated below dorsal-fin base and along midlateral line of caudal peduncle. Dorsal fin with few chromatophores extending about one-third length of basal portion of each ray. Chromatophores most intense and numerous on second dorsal-fin ray. Anal, caudal, pectoral and pelvic fins hyaline to yellowish tan without any dark chromatophores. Gonopodium of males unpigmented.

Sexual dimorphism. Proximal radials of anal-fin of mature males fused into single compound bone. Gonopodium in mature males in form of elongate, fleshy tube that originates anterior to the anal-fin base and extends one-half length of anterior margin of anal fin. Three anterior most unbranched anal-fin rays smallest and slightly curved. Fourth and fifth anal-fin rays branched and distinctly longer than other rays, with fourth ray longest. Sixth and seventh rays branched and shorter than fourth and fifth rays but longer than three anterior most rays. Posterior most (eighth) anal-fin ray short and unbranched (Fig. 2). All anal-fin pterygiophores of females separate from one another. Anal-fin rays of females with two anterior most rays shortest; remaining rays progressively longer. Anterior most anal-fin ray unsegmented and posterior most ray unbranched.

Distribution. Gelanoglanis pan is known from the type locality in the rio Teles Pires, a tributary to the upper rio Tapajós basin, Brazil (Fig. 3). Gelanoglanis pan may be an additional species endemic to the upper rio Tapajós basin (see discussion in Vari \& Calegari, 2014).

Etymology. The species name, pan, from the name of the Greek God of fertility and male sexuality, refers to the large gonopodium of the males of the species.

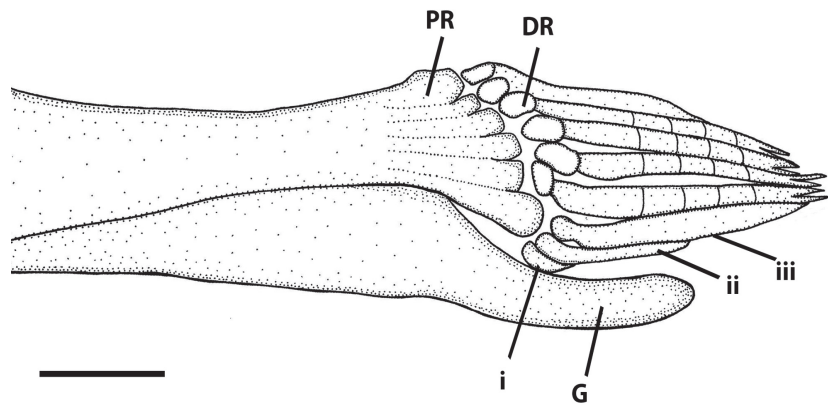

Fig. 2. Gonopodium and osteology of the anal fin of an adult male of Gelanoglanis pan, holotype, $24.7 \mathrm{~mm} \mathrm{SL}$, MZUSP 114669 , showing fusion of the proximal radials. $D R=$ distal radials, $\mathrm{G}=$ gonopodium, $\mathrm{PR}=$ fused proximal radials, $\mathrm{i}$-iii= anterior unbranched and unsegmented anal-fin rays. Scale bar $=1 \mathrm{~mm}$.

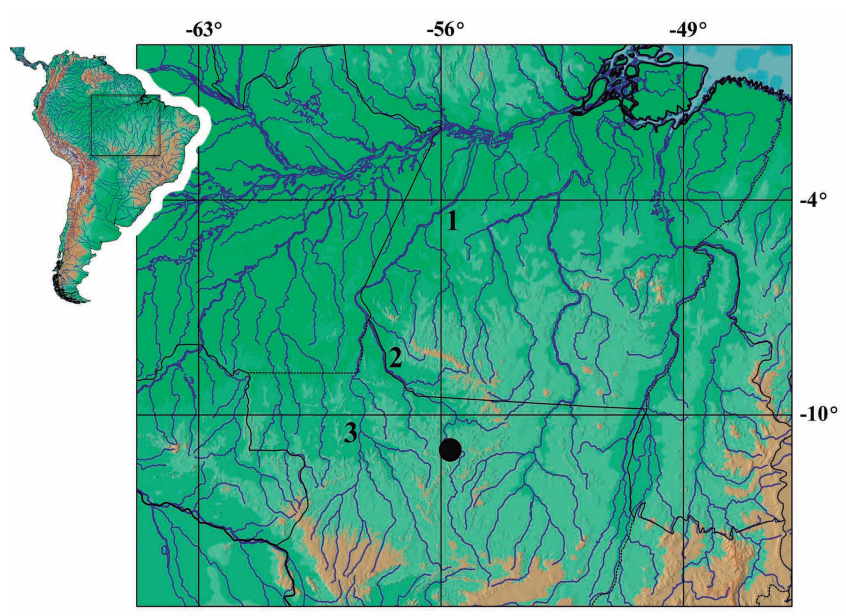

Fig. 3. Map of southeastern Amazon basin showing location of type locality of Gelanoglanis pan, 1 = rio Tapajós, 2 = rio Teles Pires, 3 = rio Juruena.

Miniaturization. Gelanoglanis pan is a miniature species under the definition proposed by Weitzman \& Vari (1988) in their overview of miniaturization within South American freshwater fishes. According to that definition, miniature fishes either mature at less than $20 \mathrm{~mm}$ SL or do not exceed a maximum body length of $26 \mathrm{~mm} \mathrm{SL}$. Although standard length is a readily observed indicator of miniaturization, Weitzman \& Vari (1988) noted that the miniaturization process generally involves a series of other less obvious reductive (paedomorphic) morphological features. Prominent among these are reductions in the degree of development of the laterosensory system on the head and body, in the number of fin rays, and of the sculpturing on the surface bones of the head.

Despite in some instances exceeding the $26 \mathrm{~mm} \mathrm{SL}$ maximum originally proposed by Weitzman \& Vari (1988), all species of Gelanoglanis share a number of reductive features and, thus, are considered miniatures. Reductions general across Gelanoglanis include the decrease to one 
ossified infraorbital, the first infraorbital; a mandibular ramus of the lateral sensory canal separate from the dentary and instead extending as a separate ossification lateral of the dentary and anguloarticular (see Fig. 4); the incomplete lateral line terminating posteriorly anterior to the caudal-fin base; the reduction of the mesethmoid to an elongate narrow arch; the very small premaxilla in the form of a thin plate bearing relatively few teeth anteriorly; and the reduction to 8 total anal-fin rays (vs. 9-11 in Tatia and Centromochlus; and 12-14 in Glanidium). Hence, Gelanoglanis pan fits the definition of a miniature both in sharing this series of developmentally truncated features with its congeners, and also in its maximum length of 24.7 $\mathrm{mm} \mathrm{SL}$.

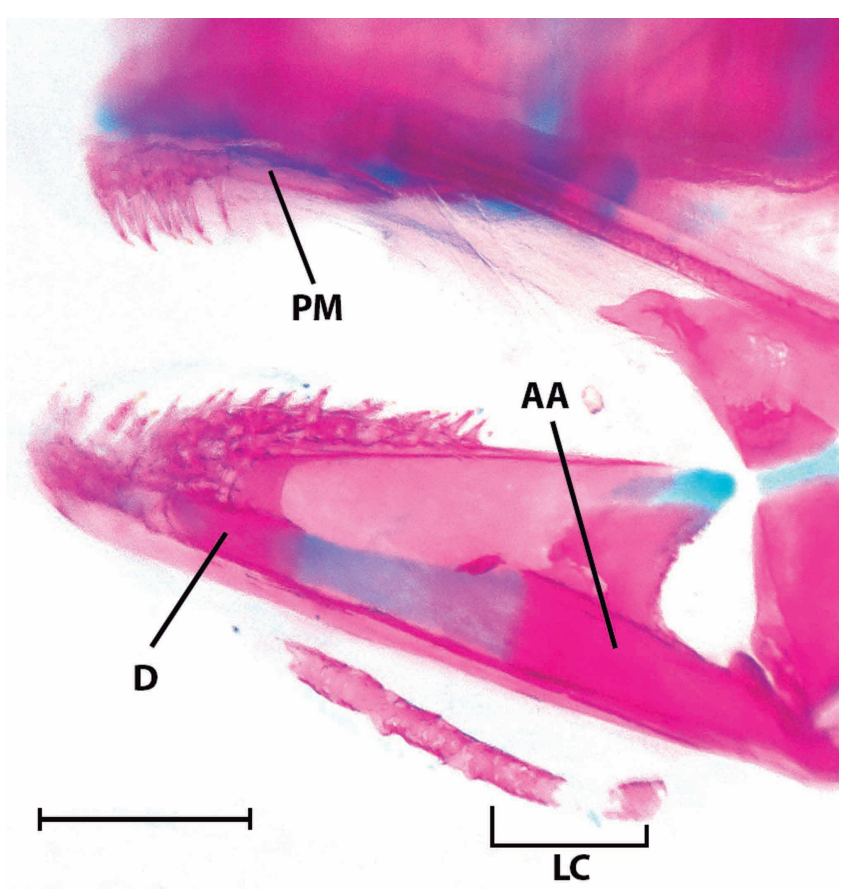

Fig. 4. Lateral view of the mandibular arch of Gelanoglanis pan, MZUSP 96032, paratype, $20.2 \mathrm{~mm}$ SL. AA = anguloarticular, $\mathrm{D}=$ dentary, $\mathrm{PM}=$ premaxilla, $\mathrm{LC}=$ subdivided autogenous laterosensory canal. Scale bar $=0.5$ $\mathrm{mm}$.

\section{Discussion}

Gelanoglanis pan is characterized by a rugose dorsal surface of the entire length of the maxillary barbel resultant from the presence of soft rounded papillae in a single series along the barbel (Fig. 5; see description for details). No comparable structures have been reported to date elsewhere in the genus. Our analysis revealed that Gelanoglanis pan shares this feature of the maxillary barbel with its congeners. The rounded papillae on the maxillary barbel were, however, encountered only in a few of the examined specimens of G. stroudi, and G. travieso. Gelanoglanis pan, conversely, possesses such structures in juveniles and adults across all examined specimens.
Further studies are necessary to throughly investigate the ontogeny of this character. Papillae-laden tissues elaborated into various structures are unusual among siluriforms although reported in several genera elsewhere in the Auchenipteridae. Ferraris \&Vari (1998; Fig. 1) documented various forms of such elaborations on the surface of the ossified maxillary barbel in mature males of Auchenipterus Valenciennes, 1840, and described a much different form of the barbel elaboration in Trachelyopterus insignis (Steindachner, 1878). Those same authors reported that the medial surface of the ossified portion of the maxillary barbel in mature males of the two then known species of Tetranematichthys Bleeker, 1858, was covered with a series of epidermal ridges (Vari \& Ferraris, 2006: 175); a modification also reported in a third species of the genus by Peixoto \& Wosiacki (2010). Fleshy elaborations of the barbel were also identified in two specimens of Pseudepapterus Steindachner, 1915, by Ferraris \& Vari (1999). The rounded fleshy elaborations of the barbel in G. pan clearly differ both in form and location from those in Auchenipterus, Pseudepapterus, Tetranematichthys, and Trachelyopterus. Another notable difference between $G$. pan versus Auchenipterus, Pseudepapterus, and Tetranematichthys is that the elaborations of the maxillary barbel in the three latter genera have been observed solely in nuptial males in which the transitory enlarged, ossified barbels are present solely during the breeding season (Ferraris \& Vari, 1999, 2000; Vari \& Ferraris, 2006) used to hold females during copulation. Gelanoglanis pan conversely has these elaborations well developed in both males and females, with juveniles also bearing small rounded epidermal papillae. These differences and present concepts of higher level relationships within the Auchenipteridae support the hypothesis of the independent acquisition of these modifications of the maxillary barbel in G. pan versus the other cited taxa of the Auchenipteridae.

Soares-Porto et al. (1999) reported a long adipose fin in the form a low fleshy ridge with its posterior margin attached to the body in adults of Gelanoglanis nanonocticolus. Alternatively, adults of G. pan, G. stroudi, and $G$. travieso lack such a ridge; having instead a distinct adipose fin with a posterior margin free from the middorsal surface of the body. A long middorsal ridge anterior to the adipose-fin base is common in juveniles of the genus, and its persistence in adults of $G$. nanonocticolus likely represents a paedomorphic feature.

The dorsal-fin spine was cited as absent in Gelanoglanis travieso by Rengifo et al. (2008), who rather reported a "second dorsal-fin lepidotrichium filamentous, simple, not a spine, not serrate". Our examination of a cleared and stained paratype of Gelanoglanis travieso (ANSP 182808) reveals a strong dorsal-fin spine with a distal unsegmented filament; a feature shared with G. pan. Interestingly G. pan and $G$. travieso also have in common similar coloration in preservative; albeit being readily distinguished by the characters detailed in the Diagnosis. 


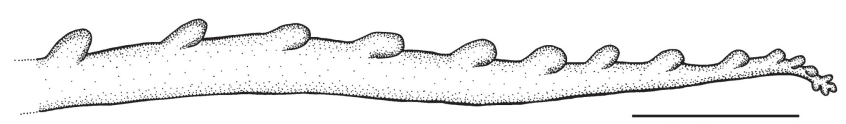

Fig. 5. Maxillary barbel of Gelanoglanis pan, MZUSP 96032, paratype, $12.6 \mathrm{~mm} \mathrm{SL}$. Left side, anterior to left. Scale bar $=0.5 \mathrm{~mm}$.

\section{Key for the species of Gelanoglanis}

1a. Dorsal and pectoral fins with spine 2

1b. Dorsal and pectoral fins lacking spine G. nanonocticolus

2a. Anterior fontanel absent; adult males with short gonopodium terminating at anal-fin origin; premaxillary teeth occupying two-thirds of length of premaxilla ...... 3

2b. Anterior fontanel present; adult males with long gonopodium extending posteriorly to midlength of base of anal fin; premaxillary teeth restricted to anterior portion of bone, occupying one-half or less of length of premaxilla (Fig. 4) G. pan

3a. Dorsal-fin spine with strong serrae along posterior margin G. stroudi

3b. Dorsal-fin spine simple, without serrae along posterior margin G. travieso

\section{Acknowledgments}

We are grateful to Fernando Jerep for discussions about characters; Flávio Lima and Paulo Petry for information on various species of Gelanoglanis; Tiago Carvalho and Mariangeles Arce (ANSP) for providing information on species of Gelanoglanis; Zeehan Jaafar to assistance with stereomicroscopic photography to comparative studies; Sandra Raredon (USNM) for the photographs and radiographs of the holotype; G. David Johnson for the photograph of the cleared and stained specimen, Jeffrey Clayton for assistance with loans at USNM; and Mark Sabaj Pérez (ANSP), David Catania (CAS), Christine Thacker and Rick Feeney (LACM), Mário de Pinna, Osvaldo Oyakawa, José Lima de Figueiredo, and Michel Gianeti (MZUSP), and Larry Page and Rob Robins (UF) for the loan and/or donation of specimens. RER thanks William Crampton for support at the University of Central Florida, where this manuscript was partially completed during a sabbatical semester. Support for this project was provided by the Conselho Nacional de Desenvolvimento Científico e Tecnológico (CNPq, process \#140439/2011-0) and Coordenação de Aperfeiçoamento de Pessoal de Nível Superior (CAPES, process \#3918/13-0) to $\mathrm{BBC} ; \mathrm{CNPq}$ (processes \#305180/2010-0 and \#207038/2013-9) and Fundação de Amparo à Pesquisa do Estado Rio Grande do Sul (FAPERGS, process \# 11/0936-5) to RER; and the Herbert R. and Evelyn Axelrod Chair in Systematic Ichthyology in the Division of Fishes, National Museum of Natural History of the Smithsonian Institution to RPV.
Comparative material examined. Ageneiosus atronasus: MCP 33179, 2 (1 c\&s), Brazil, Amazonas, Alvarões, Mata Matá lake. Ageneiosus brevis: MCP 30617, 3 (1 c\&s), Brazil, Amazonas, Tefé, rio Solimões, ilha Cuera, near Tefé. Ageneiosus piperatus: MCP 47743, 2 (1c\&s), Brazil, Amazonas, Manaus, Catajuba beach, rio Negro. Ageneiosus ucayalensis: MCP 46294, 3 (1 skl, 1 c\&s), Brazil, Pará, Itupiranga, rio Araguaia, upstream of dam of Marabá hydroeletric plant. Ageneiosus sp.: MCP 32961, 3 (1 c\&s), Brazil, Amazonas, Alvarões, rio Japurá between confluence of lago Mamirauá and rio Paraná Jaquiri. Ageneiosus uranophthalmus: MCP 35507, 2 (1 c\&s), Brazil, Acre, Rio Branco, Riozinho do Rola. Asterophysus batrachus: ANSP 158294, 3 (1 c\&s), Venezuela, Bolivar, confluence of rio Orinoco and rio Caura. Auchenipterichthys coracoideus: MCP 46293, 2 (1 c\&s), Brazil, Pará, Itupiranga, rio Tocantins basin, upstream of dam of Marabá hydroeletric plant. Auchenipterichthys punctatus: MZUSP 43137, 1 c\&s, Brazil, Amazonas, lago Curinama, four hours upstream from rio Caurés. Auchenipterichthys longimanus: MCP 46593, 4 (1 c\&s), Brazil, Roraima, Santa Maria do Baiaçú, creek Cambeua, tributary to rio Jauaperi. Auchenipterichthys thoracatus: MCP 36399, 7 (1 c\&s), Brazil, Rondônia, Jaci-Paraná, BR-364 between Porto Velho and Jaci-Paraná. Auchenipterus ambyiacus: MCP 35485, 2 (1 c\&s), Brazil, Acre, Rio Branco, Riozinho do Rola, tributary to rio Acre. Auchenipterus brevior: CAS 52135, 5 (1 c\&s), Guyana, at Tumatumari cataract. Auchenipterus nuchalis: MCP 19708, 2 (1 c\&s), Brazil, Goiás, Minaçu, rio Tocantins at Rubão harbor. Auchenipterus osteomystax: MCP 13556, 1 c\&s, Brazil, Rio Grande do Sul, Roque Gonzales, at Barra do Ijuí, creek tributary to rio Uruguay basin. Centromochlus altae: LACM 41729-42, 19 (1 c\&s), Peru, Amazonas, rio Santiago at La Poza. Centromochlus existimatus: MCP 29838, 2 (1 c\&s), Brazil, Amazonas, Alvarões, lago Mamirauá. Centromochlus heckelli: MCP 17452, 10 (1 c\&s), Brazil, Amazonas, Itacoatiara, rio Amazonas at Itacoatiara harbor. Centromochlus macracanthus: MZUSP 92986, 50 (1 c\&s), Brazil, Amazonas, rio Tiquié, between São José and Bela Vista. Centromochlus perugiae: USNM 167912 , 2 (1 c\&s), Peru, Manu, Manu National Park, Pakitza, Pachija Stream, Madre de Dios basin; MCP 45749, 5 (1 c\&s), Peru, Ucayali, Pucallpa, laguna Yarinacocha. Centromochlus romani: USNM 258227, 16 (1 c\&s), Venezuela, Guarico, rio Orituco where crossed by road from Calabozo. Centromochlus schultzi: MZUSP 94138, 7 (1 c\&s), Brazil, Mato Grosso, Gaúcha do Norte, rio Culuene, at fazenda do Sr. Zezé. Entomocorus gameroi: MCP 15135, 8 (1 c\&s), Venezuela, Soledad, Anzoategui, río Orinoco basin. Epapterus blohmi: USNM 260638, paratype, 8 (3 c\&s), Venezuela, Guarico, río Portuguesa at Camaguan; USNM 257983, paratype, 11 (2 c\&s), Venezuela, Apure, ponds along road to Modulos de Mantecal, about $4 \mathrm{~km} \mathrm{~S}$ of main road to San Fernando. Epapterus dispilurus: USNM 263115, 4 (1 c\&s), Peru, Ucayali, Utroquinia, $60 \mathrm{~km}$ from Pucallpa on the right bank, río Ucayali basin; MCP 40991, 1 c\&s, Peru, Ucayali, Pucallpa, río Ucayali basin. Gelanoglanis nanonocticolus: UF 105681, paratype, and USNM 347131, paratype, Venezuela, Amazonas, río Asisi, 22-30 $\mathrm{km}$ upstream of confluence with río Paru, Orinoco basin; ANSP 191344, 1, Venezuela, río Ventuari, dowstream end of extensive, ca. $1 \mathrm{~km}$ below Salto Tencua, $227 \mathrm{~km}$ east-southeast of Puerto 
Ayacucho, Orinoco basin. Gelanoglanis stroudi: ANSP 142937, holotype, ANSP 142939, paratype, and ANSP 142940, paratype, $1 \mathrm{c \& s}$, Colombia, Meta, río Metica, $22 \mathrm{~km} \mathrm{SW}$ of Puerto Lopez and $3 \mathrm{~km}$ SE of Hacienda Mozambique, río Meta drainage; ANSP 142941, paratype, $1 \mathrm{c \& s}$, Colombia, Meta, río Manacacias, across bridge, E of Puerto Gaitán; LACM 44411.1, 23 ( 1 c\&s), Colombia, Puerto Gaitán, río Manacacias, río Meta basin. Gelanoglanis travieso: ANSP 182808, paratype (1 c\&s), and ANSP 182807, paratype, Peru, Amazonas, Condorcanqui, río Nieva. Gelanoglanis sp.: MZUSP 92985, 10 of 142, Brazil, Amazonas, rio Tiquié, between São José and Bela Vista. Liosomadoras oncinus: MCP 46029, 7 (1 c\&s), Brazil, Amazonas, Barcelos, creek ApanhaLuz, $20 \mathrm{~km}$ below Barcelos. Pseudauchenipterus affinis: MZUSP 51718, 1 c\&s, Brazil, Espírito Santo, Linhares, rio Doce, on bridge of BR-101; MZUSP 51720, 1 c\&s, Brazil, Espírito Santo, São Mateus. Pseudauchenipterus flavescens: MZUSP 51741, 24 (1 c\&s), Brazil, Alagoas, Penedo, rio São Francisco, at ferry port. Pseudauchenipterus jequitinhonhae: MZUSP 40230, 2 c\&s, Brazil, Minas Gerais, Itira, at confluence of rio Jequitinhonha and rio Araçuai. Pseudauchenipterus nodosus: USNM 320036, 156 (2 c\&s), French Guiana, Fleuve Mahury at Le Degrad des Cannes, near Cayenne; USNM 226107, 12 (1 c\&s), Suriname, Nickerie District, Corantijn River, Clara creek. Tatia boemia: MCP 44263, 6 (1 c\&s), Brazil, Rio Grande do Sul, Nonoai, rio Passo Fundo, at Monjolinho hydroeletric plant. Tatia brunnea: MZUSP 84977, 35 (1 c\&s), Brazil, Amazonas, rio Tiquié, between Pedra Curta rapids and São Pedro. Tatia galaxias: SU 53627, 17 (2 c\&s), Venezuela, Bolivar, Caño de Quiribana near Caicara. Tatia gyrina: MCP 46589, 2 (1 c\&s), Brazil, Roraima, Santa Maria do Baiaçu, creek Cambeua, tributary to rio Jauaperi; MCP 36339, 8 (1 c\&s), Brazil, Rondônia, Porto Velho, creek Taquarás on BR-425, near to Guajará-Mirim. Tatia intermedia: MCP 29852, 2 (1 c\&s), Brazil, Amazonas, Alvarões, lago Jaraqui, rio Jarauá system. Tatia jacaratia: MZUSP 109792, 11 (1 c\&s), Brazil, Paraná, Capanema, rio Iguaçu, Parque Nacional do Iguaçu. Tatia meesi: MZUSP 109086, 18 (1 c\&s), Guyana, Potaro-Siparuni, Kuribrong River. Tatia neivai: MZUSP 109794, 11 (1 c\&s), Brazil, Paraná, Capanema, rio Iguaçu, at Parque Nacional do Iguaçu. Tatia nigra: MCP 46029, 7 (1 c\&s), Brazil, Amazonas, Barcelos, creek ApanhaLuz, $20 \mathrm{~km}$ downstream from Barcelos. Tatia strigata: USNM 338006, 3 (1 c\&s); MCP 46595, 3 (1 c\&s), Brazil, Roraima, Santa Maria do Baiaçu, creek Cambeua, rio Jauaperi. Trachelyichthys decaradiatus: MZUSP 92829, 90 (1 c\&s), Brazil, Pará, Santarém, Juá creek, $7 \mathrm{~km}$ from Santarém. Trachelyichthys exilis: MCP 29678, 2 (1 c\&s), Brazil, Amazonas, Tefé, rio Tefé, at Ilha do Martelo. Tetranematichthys wallacei: MCP 27174, 2 (1 c\&s), Brazil, Pará, Ourém, rio Guamá, near Ourém. Trachelyopterus amblops: USNM 273047, 4 (1 c\&s), Panama, Darien Province, río Pirre, 3-5 miles above El Real. Trachelyopterus insignis: CAS 77296, 1 c\&s, Colombia, Magdalena, El Banco. Trachelyopterus striatulus: MCP 44926, 5 (1 c\&s), Brazil, Minas Gerais, Leme do Prado, Ribeirão Correntes in Mandaçaia. Trachelyopterus teaguei: MCP 46875, 4 (1 c\&s), Brazil, Rio Grande do Sul, Cerro Largo, rio Ijuí near São José hydroeletric plant. Trachycorystes trachycorystes: ANSP 179152, 1 skeleton, Guyana, Rupununi, Simoni River, near Karanambo Ranch.

\section{Literature Cited}

Birindelli, J. L. O. 2010. Relações Filogenéticas da superfamília Doradoidea (Ostariophysi: Siluriformes). Unpublished Ph.D. Dissertation, Museu de Zoologia da Universidade de São Paulo, São Paulo, 377p.

Böhlke, J. E. 1980. Gelanoglanis stroudi: A new catfish from the Rio Meta system in Colombia (Siluriformes, Doradidae, Auchenipterinae). Proceedings of the Academy of Natural Sciences of Philadelphia 132: 150-155.

Ferraris, C. J., Jr. 1988. The Auchenipteridae: Putative monophyly and systematics, with a classification of the neotropical Doradoid catfishes (Ostariophysi: Siluriformes). Unpublished Ph.D. Dissertation, City University of New York, New York, 229 p.

Ferraris, C. J., Jr. 2007. Checklist of catfishes, recent and fossil (Osteichthyes: Siluriformes), and catalogue of siluriform primary types. Zootaxa, 1418:1-628.

Ferraris, C. J., Jr. \& R. P. Vari. 1999. The South American catfish genus Auchenipterus Valenciennes, 1840 (Ostariophysi: Siluriformes: Auchenipteridae): monophyly and relationships, with a revisionary study. Zoological Journal of the Linnean Society, 126: 387-450.

Ferraris, C. J., Jr. \& R. P. Vari. 2000. The deep-water South American catfish genus Pseudepapterus (Ostariophysi: Auchenipteridae). Ichthyological Explorations of Freshwaters, 11: 97-112.

Peixoto, L. A. W. \& W. B. Wosiacki. 2010. Description of a new species of Tetranematichthys (Siluriformes: Auchenipteridae) from the lower Amazon basin, Brazil. Neotropical Ichthyology, 8: 69-75.

Rengifo, B., N. K. Lujan, D. Taphorn \& P. Petry. 2008. A new species of Gelanoglanis (Siluriformes: Auchenipteridae) from the Marañon River (Amazon Basin), northeastern Perú. Proceedings of the Academy of Natural Sciences of Philadelphia, 157: 181188.

Sarmento-Soares, L. M. \& R. F. Martins-Pinheiro. 2008. A systematic revision of Tatia (Siluriformes: Auchenipteridae: Centromochlinae). Neotropical Ichthyology, 6: 495-542.

Soares-Porto, L. M. 1998. Monophyly and interrelationships of the Centromochlinae (Siluriformes: Auchenipteridae). Pp. 331-350. In: L. R. Malabarba, R. E. Reis, R. P. Vari, Z. M. Lucena \& C. A. S. Lucena (eds.). Edipucrs, Porto Alegre.

Soares-Porto, L. M., S. Walsh, L. Nico \& J. Netto. 1999. A new species of Gelanoglanis from the Orinoco and Amazon River basins, with comments on miniaturization within the genus (Siluriformes: Auchenipteridae: Centromochlinae). Ichthyological Exploration of Freshwaters 10: 63-72.

Taylor, W. R. \& G. C. Van Dyke. 1985. Revised procedures for staining and clearing small fishes and other vertebrates for bone and cartilage study. Cybium 9: 107-119.

Vari, R. P. \& C. J. Ferraris, Jr. 2006. The cattish genus Tetranematichthys (Auchenipteridae). Copeia, 2006: 168-180.

Vari, R. P. \& B. B. Calegari. 2014. New species of the catfish genus Tatia (Siluriformes: Auchenipteridae) from the rio Teles Pires, upper rio Tapajós basin, Brazil. Neotropical Ichthyology, 12(4).

Weitzman, S. H. \& R. P. Vari. 1988. Miniaturization in South American freshwater fishes; an overview and discussion. Proceedings of the Biological Society of Washington, 101: 444-465.

Submitted December 23, 2013

Accepted June 10, 2014 by Francisco Langeani

Published December 27, 2014 